\title{
Performance of Frontline Demonstrations on Productivity and Profitability of Black Gram (Vigna mungo) in Rainfed Condition of Uttar-Bastar Kanker
}

\author{
Birbal Sahu, Chandu Lal Thakur*, Suresh Kumar Markam and Upendra Kumar Nag
}

Krishi Vigyan Kendra, Kanker, Chhattisgarh (494334), India

*Corresponding author

\section{A B S T R A C T}

The study was carried out to evaluate the performance of improved cultivars with scientific package and practices on production, productivity and profitability of blackgram. Cluster frontline demonstrations were conducted during 2016-17,

\section{Keywords}

Blackgram,

FLD and

Extension gap

Article Info

Accepted:

15 March 2020

Available Online:

10 April 2020 2017-18 and 2018-19 for evaluation of the performance of Pratap Urd-1, variety of blackgram in Bhaisakatta, Badatola, Albeda, Mode, Turakhar, Choriya, Puswada and Kapasi of Uttar-Bastar Kanker district and record the feedback information of farmer's. The results revealed that the average yield of blackgram in cluster frontline Demonstrations were $6.16 \mathrm{q} \mathrm{ha}^{-1}$ as compare to $4.34 \mathrm{q} \mathrm{ha}^{-1}$ recorded in farmer's practice with average yield increment of 41 per cent and additional return of 20613 and $12067 \mathrm{Rs} \mathrm{ha}^{-1}$, respectively. It was observed that the benefit cost ratio (B: C) of recommended practice (CFLD's) were 2.24 as compared to 1.85 in farmer's practice during consecutive years of study. The average extension gap $1.83 \mathrm{q} \mathrm{ha}^{-1}$ and average technology gap $5.88 \mathrm{q} \mathrm{ha}^{-1}$ was recorded. Therefore, the results clearly indicates that the use of improved varieties and package and practices with scientific intervention under frontline demonstration programme contribute to increase the productivity and profitability of blackgram in UttarBastar Kanker district of Chhattisgarh.

\section{Introduction}

Pulses have great importance in Indian agriculture as they have rich source of protein (17 to 25 per cent) as compared to that of cereals (6 to 10 per cent), their ability to fix atmospheric nitrogen and improve the soil fertility. Among pulses, black gram is one of the most important crop. Protein malnutrition is prevalent among men, women and children in India. Pulses contribute 11 per cent of the total intake of proteins in India (Reddy, 2010). In India, frequency of pulses consumption is much higher than any other source of protein, which indicates the importance of pulses in their daily food habits. Keeping the cheapest source of protein, it is important to increase pulses 
production to provide a balanced diet among the socially and economically backward classes. Pulses are water saving crops and more than 92 per cent of the area under pulses is rainfed. About 23 million tons of pulses are need to be imported every year to meet the domestic demand. The yield of pulses is less than the global average. Adoption levels for several components of the improved production technology of the crop were low emphasizing the need for better dissemination. Several biotic, abiotic and socio-economic constraints inhibit exploitation of the yield potential of black gram and these are needed to be addressed. Crop growth and yield are limited through poor plant nutrition and uncertain water availability during the growth cycle of the crop. Inappropriate management may further reduce the fertility of soil (Rabbinge, 1995).

The major constrains or lower yield of black gram is mainly attributed to their cultivation on poor soils with inadequate and imbalanced nutrition, use of age old varieties, lack of seed treatment, weed management and pest management (Shetty et al., 2013). Front line demonstration (FLD) is one of the most powerful tools of extension because farmers, in general, are driven by the perception that "Seeing is believing". The main objective of front line demonstrations is to demonstrate newly released crop production and protection technologies and its management practices in the farmer's field. During demonstration in the farmer's field, scientists are required to study the factors contributing higher crop production, field production constraints and there by convince the farmer to adopt the technology for higher yield. Here in front line demonstration farmer's participatory approach is very useful method of owning and continuous interacting with scientists and getting the useful tips for getting higher yield in farmers own field which otherwise get lower yields (Bhargau et al., 2017) and
(Thakur et al., 2016). Keeping this in view Frontline demonstrations on black gram were conducted to demonstrate the production potentials and economic benefits of latest improved technologies of black gram among tribal farmers of Uttar-Bastar Kanker District of Chhattisgarh.

\section{Materials and Methods}

Front line demonstration (FLDs) on blackgram was conducted by Krishi Vigyan Kendra, Kanker (Chhattisgarh), India during the period from $2015-16$ to $2018-19$ in 08 villages viz., Bhaisakatta, Badatola, Albeda, Mode, Turakhar, Choriya, Puswada and Kapasi of Uttar-Bastar Kanker district. Total 140 demonstrations were conducted. In general soil of the area under study was sandy loam with low to medium fertility status. The component demonstration of front line technology in blackgram was comprised i.e. improved variety pratap urd-1, proper tillage, seed rate and sowing method, seed treatment with trichoderma@10 $\mathrm{gm} \mathrm{kg}^{-1}$ of seed, balance dose of fertilizer $(20 \mathrm{~kg} \mathrm{~N}+40 \mathrm{~kg}$ $\mathrm{P}_{2} \mathrm{O}_{5}+20 \mathrm{~kg} \mathrm{~K}_{2} \mathrm{O} \mathrm{ha}^{-1}$ ), weed management and plant protection measures (Table 1). Total 60 ha area was covered in three consecutive years. In the demonstration, one control plot was also kept where farmers practices was carried out. The FLD was conducted to study the technology gap between potential yield and demonstrated yield, extension gap between demonstrated yield and yield under existing practice and technology index. The yield data were collected from both the demonstration and farmers practice by random crop cutting method and analyzed by using simple statistical tools. The technology gap, extension gap and technological index (Samui et al., 2000) were calculated by using following formula as given below:

Demonstration yield - Farmer practice yield 
Per cent increase yield $=$

Demonstration yield - Farmer practice yield $\mathrm{x} 100$

Farmer practice yield

Technology gap $=$

Potential yield - Demonstration yield.

Extension gap $=$

Potential yield - Demonstration yield

Technology index

x 100

Potential yield

\section{Results and Discussion}

The gap between the existing and recommended technologies of blackgram in Uttar-Bastar Kanker district was presented in table 1. Full gap was observed in case of HYVs, seed treatment, fertilizer dose and weed management whereas, partial gap was observed in spacing and plant protection measure, which definitely was the reason of not achieving potential yield. Farmers were not aware about recommended technologies. In general, farmers used local or age old varieties instead of the recommended high yielding and disease resistant varieties. Unavailability of seed in time and lack of awareness were the main reasons.

\section{Grain yield}

Using three years of FLD results obtained are presented in table 2 . The data revealed that the average yield was recorded $6.16 \mathrm{q} \mathrm{ha}^{-1}$ in the demonstrated field which was 41 per cent higher than the farmers practice $4.33 \mathrm{q} \mathrm{ha}^{-1}$. The highest yield $7.24 \mathrm{q} \mathrm{ha}^{-1}$ was found in demonstrated plot during 2017-18 and $4.80 \mathrm{q}$ $\mathrm{ha}^{-1}$ under farmers practice in 2017-18.

This results clearly indicated that the higher average grain yield in demonstration plots over the years compare to farmers practice due to knowledge and adoption of full package of practices i.e. suitable varieties such as pratap urd 1, timely sowing, seed treatment, use of balance dose of fertilizer, timely weed management and need based plant protection. The yield of blackgram could be increased over the yield obtained under farmers practice (use of age old variety, improper sowing, imbalance use of fertilizer and plant protection measures) of blackgram cultivation. The above findings are in similarly with the findings of Singh (2002).

\section{Technology and extension gap}

The technology gap were $1.20,7.76$ and 8.54 q ha ${ }^{-1}$ during 2016-17, 2017-18 and 2018-19, respectively. On an average technology gap in the three years FLD programme was $5.88 \mathrm{q}$ $\mathrm{ha}^{-1}$. The technology gap observed may be attributed to dissimilarity in the soil fertility status, agricultural practices and local climatic situation.

The Extension gap of 1.00, 2.64 and $1.86 \mathrm{q}$ $\mathrm{ha}^{-1}$ were observed during 2016-17, 2017-18 and 2018-19, respectively. On an average extension gap was observed $1.83 \mathrm{q} \mathrm{ha}^{-1}$, which emphasized the need to educate the farmers through various extension means. The technology index varied from 20 to 56.93 per cent (Table 2). On an average technology index was observed 42.88 per cent, which shows the efficacy of good performance of technical interventions. This will accelerate the yield performance of blackgram (Bhargav et al., 2017).

\section{Economics}

The economic viability of improved technologies over farmer' practices were calculated depending on prevailing prices of inputs and outputs costs (Table 3 ). 
Table.1 Differences between improved practice and farmers practices under front line demonstration on Blackgram

\begin{tabular}{|c|c|c|c|c|}
\hline S. No. & Component & Improved practice & Farmers practice & Gap \\
\hline 1 & Farming Situation & Rainfed & Rainfed & Nil \\
\hline 2 & Land preparation & Three ploughing & Three ploughing & Nil \\
\hline 3 & Variety & Improved variety (Pratap Urd 1) & Age old variety & Full \\
\hline 4 & Seed rate & $20 \mathrm{~kg} \mathrm{ha}^{-1}$ & $30 \mathrm{~kg} \mathrm{ha}^{-1}$ & Higher seed rate \\
\hline 5 & Seed treatment & Trichoderma@10 $\mathrm{g} \mathrm{kg}^{-1}$ of seed & No seed treatment & Full \\
\hline 6 & Sowing method & $\begin{array}{l}30 \times 10 \mathrm{~cm} \text {, line sowing with seed cum } \\
\text { fertilizer drill. }\end{array}$ & Broadcasting & Full \\
\hline 7 & Plant population & Optimum & Uneven Distribution & Full \\
\hline 8 & Fertilizer dose & $20 \mathrm{~kg} \mathrm{~N}+40 \mathrm{~kg} \mathrm{P}_{2} \mathrm{O}_{5}+20 \mathrm{~kg} \mathrm{~K}_{2} \mathrm{O} \mathrm{ha}^{-1}$ & Imbalance and Inadequate & Full \\
\hline 9 & Weed management & $\begin{array}{l}\text { Imazethapyr 10 SL @ } 75 \text { g a.i. ha }{ }^{-1} \text { at } \\
\text { 15-20 DAS }\end{array}$ & $\begin{array}{l}\text { Weed management is not } \\
\text { common }\end{array}$ & Full \\
\hline 10 & Plant protection & $\begin{array}{l}\text { Two sprays of Thiamethoxam } 25 \text { WG @ } \\
0.5 \mathrm{ml} \text { per litre of water at } 30 \text { and } 45 \\
\text { days for sucking pest and one spray of } \\
\text { Profenophos } 50 \text { EC @ } 1.0 \text { litre a.i. ha }{ }^{-1} \\
\text { for leaf eating caterpillar. }\end{array}$ & $\begin{array}{l}\text { Plant protection is not } \\
\text { common }\end{array}$ & Partial \\
\hline
\end{tabular}


Table.2 Productivity, extension gap, technology gap and technology index of blackgram as grown under FLD and existing package of practices

\begin{tabular}{|c|c|c|c|c|c|c|c|c|c|c|}
\hline \multirow[t]{2}{*}{ Year } & \multirow{2}{*}{$\begin{array}{c}\text { Area } \\
\text { (ha) }\end{array}$} & \multirow{2}{*}{$\begin{array}{c}\text { No. of } \\
\text { Demonstration }\end{array}$} & \multirow[t]{2}{*}{ Variety } & \multicolumn{3}{|c|}{ Average yield $\left(\mathrm{q} \mathrm{ha}^{-1}\right)$} & \multirow{2}{*}{$\begin{array}{c}\text { \% increase } \\
\text { in yield over } \\
\text { farmer } \\
\text { practice }\end{array}$} & \multirow{2}{*}{$\begin{array}{l}\text { Extension } \\
\operatorname{gap}_{\left(\mathrm{qha}^{-1}\right)}\end{array}$} & \multirow{2}{*}{$\begin{array}{l}\text { Technology } \\
\operatorname{gap}_{\left(\mathbf{q} \mathbf{h a}^{-1}\right)}\end{array}$} & \multirow{2}{*}{$\begin{array}{l}\text { Technology } \\
\text { Index }\end{array}$} \\
\hline & & & & Potential & Demonstration & $\begin{array}{c}\text { Farmers } \\
\text { practice }\end{array}$ & & & & \\
\hline 2016-17 & 20 & 50 & Pratap Urd 1 & 10 & 4.80 & 3.80 & 26 & 1.00 & 1.20 & 20.00 \\
\hline 2017-18 & 20 & 45 & Pratap Urd 1 & 10 & 7.24 & 4.80 & 57 & 2.64 & 7.76 & 51.73 \\
\hline 2018-19 & 20 & 45 & Pratap Urd 1 & 10 & 6.46 & 4.60 & 40 & 1.86 & 8.54 & 56.93 \\
\hline \multicolumn{5}{|c|}{ Average } & 6.16 & 4.34 & 41 & 1.83 & 5.88 & 42.88 \\
\hline
\end{tabular}

Table.3 Economics of blackgram through front line demonstration

\begin{tabular}{|c|c|c|c|c|c|c|c|c|}
\hline \multirow{2}{*}{ Year } & \multicolumn{2}{|c|}{$\begin{array}{c}\text { Average cost of cultivation } \\
\text { (Rs/ha) }\end{array}$} & \multicolumn{2}{c|}{$\begin{array}{c}\text { Average gross return } \\
\text { (Rs/ha) }\end{array}$} & \multicolumn{2}{c|}{$\begin{array}{c}\text { Average net return } \\
\text { (Rs/ha) }\end{array}$} & \multicolumn{2}{|c|}{ Benefit cost ratio } \\
\cline { 2 - 9 } & Demonstration & $\begin{array}{c}\text { Farmers } \\
\text { practice }\end{array}$ & Demonstration & $\begin{array}{c}\text { Farmers } \\
\text { practice }\end{array}$ & $\begin{array}{c}\text { Demonstration } \\
\text { Farmers } \\
\text { practice }\end{array}$ & $\begin{array}{c}\text { Demonstration } \\
\text { Farmers } \\
\text { practice }\end{array}$ \\
\hline $\mathbf{2 0 1 6 - 1 7}$ & 17500 & 16200 & 36000 & 28500 & 18500 & 12300 & 2.06 \\
\hline $\mathbf{2 0 1 7 - 1 8}$ & 16400 & 14200 & 43440 & 27600 & 27040 & 13400 & 2.65 \\
\hline $\mathbf{2 0 1 8 - 1 9}$ & 16000 & 12500 & 32300 & 23000 & 16300 & 10500 & 2.02 \\
\hline Average & $\mathbf{1 6 6 3 3}$ & $\mathbf{1 4 3 0 0}$ & $\mathbf{3 7 2 4 7}$ & $\mathbf{2 6 3 6 7}$ & $\mathbf{2 0 6 1 3}$ & $\mathbf{1 2 0 6 7}$ & $\mathbf{2 . 2 4}$ \\
\hline
\end{tabular}

* MSP of blackgram @ Rs. 5000.00 qt ${ }^{-1}$ in 2016-17, Rs. $5400.00 \mathrm{qt}^{-1}$ in 2017-18 and Rs. 5600.00 $\mathrm{qt}^{-1}$ in 2018-19. 
It was found that cost of cultivation of blackgram varied from Rs. 16000 to Rs. $17500 \mathrm{ha}^{-1}$ with an average of Rs. $16633 \mathrm{ha}^{-1}$ of demonstration as against the variation in cost of cultivation from Rs. 16200 to Rs. $12500 \mathrm{ha}^{-1}$ with an average of Rs. $14300 \mathrm{ha}^{-1}$ in farmers practice. Cultivation of blackgram in the demonstration gave higher net return ranged from Rs. 16300 to Rs. $27040 \mathrm{ha}^{-1}$ with a mean value of Rs. 20613 ha $^{-1}$ as compared to farmers practice which recorded Rs. 10500 to Rs. $13400 \mathrm{ha}^{-1}$ with a mean of Rs. 12067 $\mathrm{ha}^{-1}$. The higher benefit cost ratio 2.06, 2.65 and 2.02 were found under demonstration compared to $1.76,1.94$ and 1.84 under farmers practice in the corresponding seasons. The higher net returns and $\mathrm{B}$ : $\mathrm{C}$ ratio in blackgram demonstration might be due to the higher grain yield and better pricing of the produce in the market. These results in accordance with the findings of Dhaka et al., (2010).

In conclusion, use of improved package of practices viz., improved variety, weed management, improved method of sowing, nutrient and pest management may enhance the crop yield in the Uttar-Bastar Kanker district especially in upland situation were rice crop is not economically. From the economic point of view blackgram is more remunerative crop as compare to other upland crop in the district.

\section{References}

Bhargav, K.S., Khedkar, N.S., Gayatri, G.R. and Gupta, N. (2017). Evaluation of front line demonstration on chickpea and pigeonpea in Shajapur District of MP. International Journal of Pure Applied Bioscience, 5(5): 293-297.

Dhaka, B.L, Meena, B.S. and Suwalka, R. L. (2010). Popularization of improved maize technology through frontline demonstration in South-eastern Rajasthan. Journal of Agricultural Sciences, (1): 3942.

Rabbinge, R. (1995). Ecoregional approaches, why, what and how. In: Ecoregional approaches for sustainable land use and food production (Bouma, J., Kuybenhoven, J., Bouman, J., Luyten, C. and Zandastra, H.G. Ed). Kluwer Academic Publishers, Dordrecht, the Netherlands.

Reddy, A.A. (2010). Regional disparities in food habits and nutritional intake in Andhra Pradesh, India, Regional \& Sectoral Econ, 10(2):125-134.

Samui, S., Maitra, K.S., Roy, D.K., Mondal, A.K. and Saha, D. (2000). Evaluation on front line demonstration on groundnut (Arachis hypogea L.). Journal of Indian Society of Coastal Agriculture Research, 18: 180-183.

Shetty, P.K., Ayyappan, S. and Swaminathan, M.S. (2013). Climate change and sustainable food security. ISBN: 978-8187663-76-8, National Institute of Advanced Studies, Bangalore and Indian Council of Agricultural Research, New Delhi.

Thakur, A.P. and Shuryabhushan. (2016). Economic impact of front line demonstrations on cereal and pulse crops in Godda district of Jharkhand. Journal of Economic \& Social Development, 12(2):106-111.

\section{How to cite this article:}

Birbal Sahu, Chandu Lal Thakur, Suresh Kumar Markam and Upendra Kumar Nag. 2020. Performance of Frontline Demonstrations on Productivity and Profitability of Black Gram (Vigna mungo) in Rainfed Condition of Uttar-Bastar Kanker. Int.J.Curr.Microbiol.App.Sci. 9(04): 1898-1903. doi: https://doi.org/10.20546/ijcmas.2020.904.224 